\title{
Parental perception and child's nutritional status
}

\author{
S. Songül Yalçın ${ }^{1}$, Esra Serdaroğlu², O. Tolga İnce ${ }^{1}$ \\ Unit of ${ }^{1}$ Social Pediatrics and ${ }^{2}$ Pediatric Neurology, Hacettepe University Faculty of Medicine, Turkey. \\ E-mail: siyalcin@hacettepe.edu.tr \\ Received: 3 June 2015, Revised: 15 September 2015, Accepted: 1 October 2015
}

\begin{abstract}
SUMMARY: Yalçın SS, Serdaroğlu E, İnce OT. Parental perception and child's nutritional status. Turk J Pediatr 2016; 58: 63-68.

Childhood obesity is a health hazard increasing worldwide. Preschool period which is under supervision of parents is a critical period to detect overweight and take precautions. We studied the factors affecting parental estimation of their preschool child's weight. Three hundred sixty seven mothers completed questionnaires consisting of child's and parents' anthropometric measurements, parents' assessment of their child's and their own weight status, and general information about their lifestyle. Mothers also chose their wish for current and future body image of their child from child drawings representing percentiles. Child body mass index-for-age $z$ score (BAZ) was related to birth weight and child's appetite. BAZ was not related to child's gender, presence of chronic disease, family pattern, parental age, education or income. $43.1 \%$ of mothers correctly assessed child's BAZ verbally. Maternal verbal estimation was correlated with maternal visual estimation, paternal verbal estimation and child's BAZ. Mothers' wish for future figure of the child was not related to child's BAZ, but showed correlation with mothers' wish for current figure of the child. Mother's correct perception of her child's weight was found to be high, consistent with her spouse and related to child's BAZ.
\end{abstract}

Key words: childhood obesity, perception, body mass index.

Childhood overweight and obesity continue in adulthood ${ }^{1}$ and anticipate diabetes and cardiovascular diseases at an earlier age ${ }^{2-}$ 4. According to World Health Organisation (WHO) 17.6 million children below five years of age tend to be obese ${ }^{5}$. In Turkey overweight in children under 5 years is $5.8 \%^{6}$. Among school-age children aged 6-9 years, $14.3 \%$ were overweight and $6.5 \%$ were obese in $2011^{7}$. Another study including 4958 Turkish children aged 7-8 years revealed that $23.3 \%$ of boys and $21.6 \%$ of girls were overweight ${ }^{8}$.

First step to preventing childhood obesity is to identify children overweight ${ }^{4,9}$. Parents need to recognize and prepare to take caution about their child's overweight. Studies in different populations have found that majority of parents fail to evaluate their child's weight status $4,10,11$. Misperception and less concerns for future are especially high among parents of preschool children ${ }^{4,12}$. Parents concern was found to be only modestly related to body mass index (BMI) ${ }^{13}$. Questionnaires based on verbal or visual tools both reveal high levels of underestimation of weight status, although with verbal tools accuracy rates seem to be higher ${ }^{14}$. Parental misperception might be related to different factors ${ }^{15}$ such as lower maternal education ${ }^{16}$, maternal age ${ }^{17}$, parental body mass index ${ }^{18}$, parental self-perception ${ }^{18}$, and gender of the child ${ }^{17}$. There are limited studies about parental misperception.

The purpose of this study was to determine the factors that affect child's nutritional status. The aim is also to investigate parental perception and wish for child's nutritional status using verbal and visual assessement tools.

\section{Material and Methods}

We performed a cross-sectional descriptive questionnaire study for parents of 379 children aged 0-6 years excluding newborn period. Ethical permission was obtained from the Hacettepe University Research Ethics Committee. The research was conducted in accordance with prevailing ethical principles.

The questionnaire consisted of information 
about the child (age, sex, measured height, measured weight, birth weight, onset of supplementary feeding, total breastfeeding period, vitamin and iron intakes, diagnosis of a chronic disease); about the family (number of children, number of household, parents' age, education, job, weight and height, total monthly income); assessment of child by mother regarding appetite and weight, father's perception of child's weight, perception of her own and child's father's weight.

Concern for child weight was assessed with three questions about parental concerns for children eating too much and attaining a desirable body weight. Responses were quantified by converting to numbers $1-5$. Perceived child weight was assessed by three verbal questions that asked parents to classify children's weight. Parents rated perceived child weight on a 7-point categorical scale ranging from "markedly underweight" to "markedly overweight." For each subscale, responses were quantified by converting to numbers 1-7. Higher scores indicated greater perceived weight and concern.

Visual tools included picture percentiles for assessment of child's current weight, wish for current weight status, and wish for future weight status. Visual tools were adapted from Hager et al. ${ }^{19}$ and Warschburger et al. ${ }^{20}$. Visually perceived child weight and wish for present weight were assessed by 7 picture percentiles designed by Hager et al. ${ }^{19}$ without indication of gender. Visually perceived wish for future weight was assessed by 7 picture percentiles for each gender designed by Warschburger et

Table I. Child's Nutritional Status According to Child and Family Characteristics

\begin{tabular}{|c|c|c|c|c|c|c|}
\hline & & \multirow[b]{2}{*}{ Overall* } & \multicolumn{3}{|c|}{ Child's Body Mass Index** } & \multirow{2}{*}{$\begin{array}{l}\text { Correct Verbal } \\
\text { estimation }\end{array}$} \\
\hline & & & $z<-1$ & $-1 \leq z<1$ & $z \geq 1$ & \\
\hline \multirow[t]{2}{*}{ Age. mo } & $<24$ & 54.0 & 20.2 & 55.1 & 24.7 & $49.0^{c}$ \\
\hline & $\geq 24$ & 46.0 & 12.4 & 61.4 & 26.0 & 36.1 \\
\hline \multirow[t]{3}{*}{ Gender } & male & 56.7 & 14.9 & 59.6 & 25.5 & 41.3 \\
\hline & female & 43.3 & 18.9 & 56.0 & 25.2 & 45.3 \\
\hline & $<2.5$ & 13.9 & 27.5 & 58.8 & $13.7^{\mathrm{a}}$ & 41.2 \\
\hline \multirow[t]{2}{*}{ Birth weight, kg } & $2.5-3.9$ & 78.5 & 15.6 & 58.7 & 25.7 & 43.4 \\
\hline & $\geq 4.0$ & 7.6 & 7.1 & 50.0 & 42.9 & 42.9 \\
\hline \multirow{2}{*}{$\begin{array}{l}\text { Current breastfeeding } \\
\text { in children }<24 \mathrm{~m}\end{array}$} & yes & 38.4 & 23.7 & 48.7 & 27.6 & 48.7 \\
\hline & no & 61.6 & 18.0 & 59.0 & 23.0 & 49.2 \\
\hline \multirow{2}{*}{$\begin{array}{l}\text { Underlying chronic } \\
\text { disease }\end{array}$} & no & 70.3 & 15.1 & 57.8 & 27.1 & 43.0 \\
\hline & yes & 29.7 & 20.2 & 58.7 & 21.1 & 43.1 \\
\hline \multirow{4}{*}{$\begin{array}{l}\text { Child's appetite } \\
\text { according to mother }\end{array}$} & poor & 35.4 & 28.5 & 62.3 & $9.2^{\mathrm{b}}$ & 36.2 \\
\hline & normal & 42.5 & 10.3 & 57.1 & 32.7 & 45.5 \\
\hline & high & 22.1 & 9.9 & 53.1 & 37.0 & 49.4 \\
\hline & 1 & 38.4 & 12.8 & 60.3 & 27.0 & 44.7 \\
\hline \multirow[t]{2}{*}{ Number of children } & 2 & 43.1 & 20.3 & 55.7 & 24.1 & 42.4 \\
\hline & $\geq 3$ & 18.5 & 16.2 & 58.8 & 25.0 & 41.2 \\
\hline \multirow[t]{2}{*}{ Family pattern } & simple & 82.0 & 16.3 & 58.5 & 25.2 & 43.5 \\
\hline & extended & 18.0 & 18.2 & 56.1 & 25.8 & 40.9 \\
\hline \multirow[t]{2}{*}{ Family size } & $<5$ & 68.9 & 16.6 & 57.7 & 25.7 & 42.3 \\
\hline & $\geq 5$ & 31.1 & 16.7 & 58.8 & 24.6 & 44.7 \\
\hline Total & & & 16.6 & 58.0 & 25.3 & 43.1 \\
\hline
\end{tabular}

* column percentage, ${ }^{* *}$ row percentage, ${ }^{\mathrm{a}} \mathrm{p}=0.019{ }^{\mathrm{b}} \mathrm{p}<0.001{ }^{\mathrm{c}} \mathrm{p}=0.013$ 
al. ${ }^{20}$. First and last two picture percentiles representing the highest and lowest percentiles were grouped in evaluation, and converted to numbers 1-5. Higher scores indicated greater weight.

Adiposity was assessed by using $\mathrm{z}$ score for children, which was calculated by WHO Anthro according to WHO Growth Reference Study. $\mathrm{Z}$ scores were divided into groups of $\mathrm{z}<-1, \mathrm{Z}$ -1 to 1 and $z \geq 1$.

Parental BMI, calculated by weight $(\mathrm{kg})$ divided by height squared $\left(\mathrm{m}^{2}\right)$, were categorized as normal weight $\left(<25 \mathrm{~kg} / \mathrm{m}^{2}\right)$, overweight (25.0-29.9) or obese $(\geq 30)$ based on WHO cutoffs.

\section{Statistical analysis}

Statistical analyses were performed using SPSS software version 21. Descriptive statistics were performed to determine means and standard deviations for continuous variables and frequencies for categorical variables. The proportions of patients according to underweight-normal-overweight nutritional status and correct estimation were presented by child and family characteristics. The Chi-square test or Fisher's exact test, where appropriate, were used to compare the proportions in different groups. Kolmogrow-Simirnov test was used to determine whether or not the variables were normally distributed. While investigating the associations between normally distributed variables, the correlation coefficients were calculated using the Pearson test. In ordinal variables and skewed data the Spearman test was used to calculate the correlation coefficients. A p-value of less than 0.05 was considered to show a statistically significant result.

\section{Results}

Three hundred sixty seven cases between 0-6 years, with a mean age of 25.2 months $( \pm 18.8)$ (range: 1-72 month) were selected as the study group. Fifty-four percent $(\mathrm{n}=198)$ were below 24 months of age and $56.7 \%(n=208)$ were male. Mean $( \pm \mathrm{SD})$ BMI-for-age-Z-score (BAZ) was $0.28 \pm 1.45$. Maternal mean BMI $( \pm S D)$ was $25.2 \pm 4.4 \mathrm{~kg} / \mathrm{m}^{2}$, paternal mean BMI was $26.0 \pm 3.2 \mathrm{~kg} / \mathrm{m}^{2}$. Among mothers, 31.6 $\%$ were overweight and $13.9 \%$ were obese. Among fathers, $46.9 \%$ were overweight and $10.9 \%$ were obese (Table I).
Among children, $16.6 \%$ had $\mathrm{BAZ}<1$ and $25.3 \%$ had $B A Z \geq 1$. Child's nutritional status did not change with child's gender, presence of chronic disease, family pattern, parental age, education or income (Table I, Table II). Children with lower birthweight tended to be thin when they grew up (Table I). $13.7 \%$ of children with low birthweight had $B A Z \geq 1$ whereas $42.9 \%$ of children with high birthweight $(\geq 4000 \mathrm{~g})$ had $B A Z \geq 1 \quad(p=0.019)$.

Children with good appetite according to their mothers more likely had high BAZ; $9.2 \%$ of children with poor appetite, $32.7 \%$ of normal appetite and $37.0 \%$ of good appetite had $B A Z \geq 1 \quad(p<0.001)$.

There was a positive correlation between maternal and paternal BMI $(\mathrm{r}=0.212, \mathrm{p}<0.001)$. Child's BAZ was not related with maternal or paternal BMI $(r=0.046, r=0.018$ respectively; $\mathrm{p}>0.05)$.

\section{Perception}

Correct estimation of child's nutritional status was detected in $43.1 \%$ of mothers. Nutritional status of children under 24 months of age were estimated more accurately than that of older children ( $p=0.013$, Table I). Correct estimation of nutritional status changed significantly with child's BAZ (45.9\% of thin cases, $56.8 \%$ of normal and $9.7 \%$ of cases with $B A Z \geq 1$, respectively; $\mathrm{p}<0.001$, Fig. 1).

Mothers recognized their own and their husband's BMI correctly $(r=0.533 \mathrm{p}<0.001$ and $\mathrm{r}=0.541, \mathrm{p}<0.001$, respectively). Child's BAZ was correlated with maternal and paternal verbal assessment of the child's nutritional status. $(\mathrm{r}=0.517, \mathrm{r}=0.408 ; \mathrm{p}<0.001$, respectively $)$, and with maternal visual assessment of the child's nutritional status $(\mathrm{r}=0.541 ; \mathrm{p}<0.001)$. Maternal and paternal verbal assessments of the child's weight status were correlated $(r=0.705 ; p<0.001$, Fig. 2). Maternal verbal and visual assessment of child's weight status were correlated $(r=-0.620 ; p<0.001)$. Child's BAZ was not related to maternal wish for child's future figure. However, maternal wish for child's current and future figures were correlated $(r=0.477 ; p<0.001$, Fig. 2$)$.

\section{Discussion}

Of the 367 children aged 0-6 years, 93 (25.3\%) had $B A Z \geq 1$. Child's BAZ was related to birthweight and appetite. Child's BAZ had no 
Table II. Child's Nutritional Status According to Parental Characteristics

\begin{tabular}{|c|c|c|c|c|c|c|}
\hline & & \multirow[b]{2}{*}{ Overall* } & \multicolumn{3}{|c|}{ Child's Body Mass Index** } & \multirow{2}{*}{$\begin{array}{l}\text { Correct Verbal } \\
\text { estimation }{ }^{* *}\end{array}$} \\
\hline & & & $z<-1$ & $-1 \leq z<1$ & $z \geq 1$ & \\
\hline \multirow[t]{3}{*}{ Maternal age, y } & $<24$ & 18.8 & 17.4 & 55.1 & 27.5 & 40.6 \\
\hline & $24-34$ & 63.2 & 16.8 & 60.8 & 22.4 & 41.8 \\
\hline & $\geq 35$ & 18.0 & 15.2 & 51.5 & 33.3 & 50.0 \\
\hline Maternal BMI & $<25$ & 52.6 & 13.0 & 62.2 & 24.9 & 42.5 \\
\hline (missing: $1.9 \%$ ) & $\geq 25$ & 44.5 & 21.0 & 53.3 & 25.7 & 43.7 \\
\hline \multirow{2}{*}{ Maternal education } & $\leq 8 \mathrm{y}$ & 45.0 & 17.6 & 57.0 & 25.5 & 44.2 \\
\hline & $>8 y$ & 55.0 & 15.8 & 58.9 & 25.2 & 42.1 \\
\hline \multirow{2}{*}{ Maternal occupation } & housewife & 77.7 & 17.9 & 57.2 & 24.9 & 42.8 \\
\hline & working & 22.3 & 12.2 & 61.0 & 26.8 & 43.9 \\
\hline \multirow{2}{*}{ Paternal age, y } & $<35$ & 61.3 & 16.4 & 58.7 & 24.9 & 40.0 \\
\hline & $\geq 35$ & 38.7 & 16.9 & 57.0 & 26.1 & 47.9 \\
\hline Paternal BMI & $<25$ & 30.6 & 15.8 & 64.7 & 19.4 & 45.3 \\
\hline (missing: 4.4\%) & $\geq 25$ & 60.4 & 17.5 & 53.3 & 29.2 & 41.0 \\
\hline \multirow{2}{*}{$\begin{array}{l}\text { Paternal education } \\
\text { (missing: } 0.8 \% \text { ) }\end{array}$} & $\leq 8 \mathrm{y}$ & 29.7 & 19.3 & 56.0 & 24.8 & 40.4 \\
\hline & $>8 y$ & 69.5 & 15.7 & 58.4 & 25.9 & 44.3 \\
\hline \multirow[t]{3}{*}{ Family income, TL } & $<1000$ & 25.1 & 17.4 & 60.9 & 21.7 & 43.5 \\
\hline & 1000-1999 & 37.6 & 20.3 & 52.9 & 26.8 & 39.9 \\
\hline & $\geq 2000$ & 37.3 & 12.4 & 61.3 & 26.3 & 46.0 \\
\hline Total & & & 16.6 & 58.0 & 25.3 & 43.1 \\
\hline
\end{tabular}

* column percentage, ${ }^{* *}$ row percentage

BMI: body mass index, y: year, TL: Turkish Lira

relation with paternal BMI, chronic disease, gender, family pattern, parental age, income or education.

Risk of overweight and obesity in childhood were more common in cases with higher birthweight and increased appetite. In a Finnish study, babies born large for gestational age were more likely found to be obese young adults $^{21}$. Maternal responsiveness studies found that mothers were more responsive to child hunger than fullness clues ${ }^{22}$. This is consistent with the relation between appetite and BMI in our study.

Development of overweight and obesity in children are affected by parental perceptions. Rhee et al. ${ }^{18}$ studied factors on parental readiness to make changes for overweight children and found that parental perceptions of their own weight, not only their child's weight, played an important role ${ }^{18}$. Mother's BMI and body dissatisfaction may have an indirect role in weight change of their young children ${ }^{23}$. Parents in our sample were found to perceive their nutritional status correctly. $43.1 \%$ of mothers correctly assessed child's BMI verbally. We found correlation between maternal verbal and visual evaluation of the child. Adams et al. ${ }^{24}$ compared perception rates of mothers and fathers and found that fathers less likely recognized overweight in their children ${ }^{24}$. However, maternal and paternal verbal assessments of child's weight status were correlated, and related to child's BMI in our study. The GENESIS study in Greece reported that underestimation and overestimation rate changed with increasing age ${ }^{1}$. Younger children ( $<24$ months) in our study were more frequently accurately estimated than the older children. In our study, accuracy decreased if the child had $B A Z \geq 1$. About half of underweight and normal children's weight were correctly estimated whereas only $9.7 \%$ of children with $\mathrm{BAZ} \geq 1$ were accurately estimated. This finding is consistent with previous studies stating high misperception of overweight in children ${ }^{16,25-30}$. 


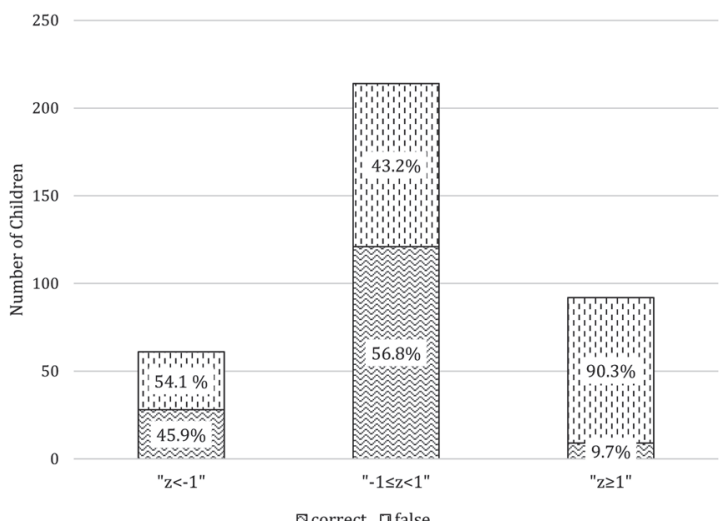

Fig. 1. Correct estimation by nutritional status $(p<0.001)$

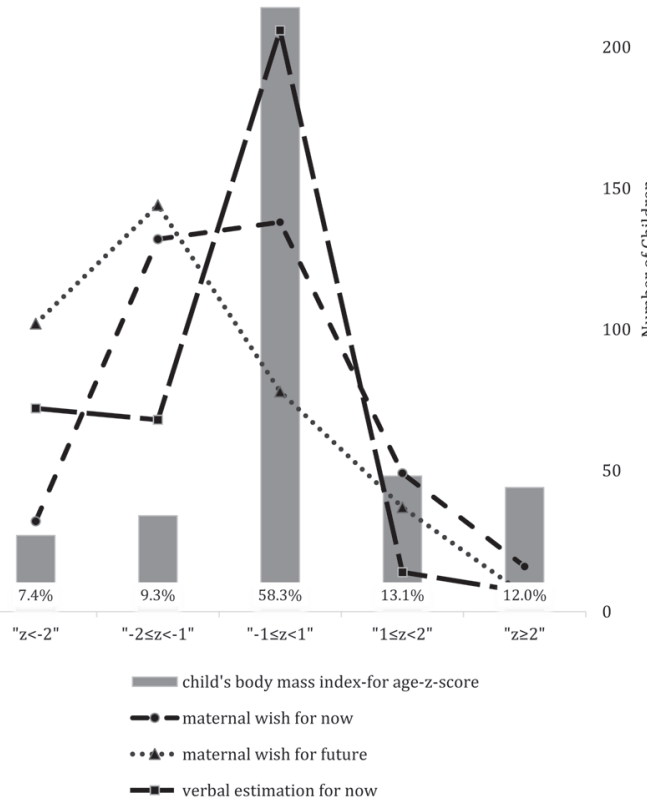

Fig 2. Maternal verbal asssesment and wish of the child's nutritional status by child's body mass index-for age-z-score

GENESIS study found that mothers with low educational level ( $<9$ years) were more likely to underestimate their child than those having higher levels of education ${ }^{1,16}$. We found no relation with maternal or paternal education. Many studies showed that the child's gender affected parental estimation, studies described boys were underestimated more ${ }^{1,26}$. However, similar to Petricevic et al.'s Croatian study ${ }^{31}$, we found no effect of gender on correct assessment.

Weight perception may vary according to ethnic groups and their country of residence ${ }^{32}$. Cultural variation in infant feeding was assessed in a recent study among Turkish and Dutch babies living in The Netherlands. Turkish mothers more often perceived their child's growth slow, and fed their babies on average one feeding per day more than Dutch mothers. Turkish mothers described chubby infants as pretty. The authors argued that according to Dutch cohorts, Turkish mothers were more likely to underestimate their children at 5 years of age and considered overweight as a sign of prosperity and good caregiving ${ }^{32}$. In our study we found that mothers' perception was highly accurate and related to BAZ. This difference of results of Turkish mothers' perception may reflect changes due to the country of residence or any other confounding factor, making generalisation based on ethnicity difficult.

\section{REFERENCES}

1. Manios Y, Kondaki K, Kourlaba G, Vasilopoulou E, Grammatikaki E. Maternal perceptions of their child's weight status: the GENESIS study. Public Health Nutr 2009; 12: 1099-1105.

2. Freedman DS, Khan LK, Serdula MK, et al. The relation of childhood BMI to adult adiposity: the Bogalusa Heart Study. Pediatrics 2005; 115: 22-27.

3. Onnerfalt J, Erlandsson LK, Orban K, et al. A familybased intervention targeting parents of preschool children with overweight and obesity: conceptual framework and study design of LOOPS- Lund overweight and obesity preschool study. BMC Public Health 2012; 12: 879.

4. Rietmeijer-Mentink M, Paulis WD, van Middelkoop M, Bindels PJ, van der Wouden JC. Difference between parental perception and actual weight status of children: a systematic review. Matern Child Nutr 2013; 9: 3-22.

5. Waxman A. Prevention of chronic diseases: WHO global strategy on diet, physical activity and health Food Nutr Bull 2003; 24: 281-284.

6. Hacettepe University Institute of Population Studies, T.R. Prime Ministry Undersecretary of State Planning Organization and TUBITAK, Ankara. Turkey Demographic and Health Survey, 2008. 2009. Available at: http://www.hips.hacettepe.edu.tr/eng/TDHS_2013 main.report.pdf

7. Sağlık Bakanlığı, Temel Sağlık Hizmetleri Genel Müdürlüğü, Hacettepe Üniversitesi Sağlık Bilimleri Fakültesi Beslenme ve Diyetetik Bölümü, Milli Eğitim Bakanlığı. Türkiye'de Okul Çağı (6-10 Yaş Grubu) Çocuklarında Büyümenin İzlenmesi (TOÇBİ) Projesi Araştırma Raporu. Ankara: Sağlık Bakanlığı Yayın No:834, Kuban Matbaa, 2011. Available at: http:// beslenme.gov.tr/content/files/yayinlar/kitaplar/diger kitaplar/tocbi_kitap.pdf 
8. Republic of Turkey Ministry of Health, Republic of Turkey Ministry of National Education, Hacettepe University. Turkey Childhood (Ages 7-8) Obesity Surveillance Initiative (COSI-TUR) 2013. Ankara: Sistem Ofset, 2014. Available at: http://beslenme. gov.tr/content/files/yayinlar/ingilizce_yayinlar/books/ cosi_key_findings-baski.pdf

9. Wofford LG. Systematic review of childhood obesity prevention. J Pediatr Nurs 2008; 23: 5-19.

10. Parry LL, Netuveli G, Parry J, Saxena S. A systematic review of parental perception of overweight status in children. J Ambul Care Manage 2008; 31: 253-268.

11. Doolen J, Alpert PT, Miller SK. Parental disconnect between perceived and actual weight status of children: a metasynthesis of the current research. J Am Acad Nurse Pract 2009; 21: 160-166.

12. Parkinson KN, Drewett RF, Jones AR, et al. When do mothers think their child is overweight? Int J Obes (Lond) 2011; 35: 510-516.

13. Wake M, Canterford L, Hardy P, Ukoumunne OC. At what BMI are parents of pre-schoolers concerned? National cross-sectional study. Int J Pediatr Obes 2011; 6: 499-501.

14. Moschonis G, Iatridi V, Mavrogianni C, et al. Accuracy and correlates of visual and verbal instruments assessing maternal perceptions of children's weight status: the Healthy Growth Study. Public Health Nutr 2011; 14: 1979-1987.

15. Keller KL, Olsen A, Kuilema L, Meyermann K, Belle C. Predictors of parental perceptions and concerns about child weight. Appetite 2013; 62: 96-102.

16. Baughcum AE, Chamberlin LA, Deeks CM, Powers SW, Whitaker RC. Maternal perceptions of overweight preschool children. Pediatrics 2000; 106: 1380-1386.

17. Souto-Gallardo MC, Jimenez-Cruz A, Bacardi-Gascon M. Parents perception of weight status of Mexican preschool children using different tools. Arch Latinoam Nutr 2011; 61: 382-388.

18. Rhee KE, De Lago CW, Arscott-Mills T, Mehta SD, Davis RK. Factors associated with parental readiness to make changes for overweight children. Pediatrics 2005; 116: e94-101.

19. Hager ER, McGill AE, Black MM. Development and validation of a toddler silhouette scale. Obesity (Silver Spring) 2010;18:397-401.

20. Warschburger P, Kroller K. Maternal perception of weight status and health risks associated with obesity in children. Pediatrics 2009; 124: e60-68.
21. Skilton MR, Siitonen N, Wurtz P, et al. High birth weight is associated with obesity and increased carotid wall thickness in young adults: the cardiovascular risk in young Finns study. Arterioscler Thromb Vasc Biol 2014; 34: 1064-1068.

22. Hodges EA, Johnson SL, Hughes SO, et al. Development of the responsiveness to child feeding cues scale. Appetite 2013; 65: 210-219.

23. Rodgers RF, Paxton SJ, McLean SA, et al. Do maternal body dissatisfaction and dietary restraint predict weight gain in young pre-school children? A 1-year follow-up study. Appetite 2013; 67: 30-36

24. Adams AK, Quinn RA, Prince RJ. Low recognition of childhood overweight and disease risk among NativeAmerican caregivers. Obes Res 2005; 13: 146-152.

25. Campbell MW, Williams J, Hampton A, Wake M. Maternal concern and perceptions of overweight in Australian preschool-aged children. Med J Aust 2006; 184: 274-277.

26. Carnell S, Edwards C, Croker H, Boniface D, Wardle J. Parental perceptions of overweight in 3-5 y olds. Int J Obes (Lond) 2005; 29: 353-355.

27. Garrett-Wright D. Parental perception of preschool child body weight. J Pediatr Nurs 2011; 26: 435-445.

28. Hackie M, Bowles CL. Maternal perception of their overweight children. Public Health Nurs. 2007; 24: 538-546.

29. Hirschler V, Gonzalez C, Talgham S, Jadzinsky M. Do mothers of overweight Argentinean preschool children perceive them as such? Pediatr Diabetes 2006; 7: 201204.

30. Myers S, Vargas Z. Parental perceptions of the preschool obese child. Pediatr Nurs 2000; 26: 23-30.

31. Petricevic N, Puharic Z, Posavec M, Pavic Simetin I, Pejnovic Franelic I. Family history and parental recognition of overweight in Croatian children. Eur J Pediatr 2012; 171: 1209-1214.

32. van Eijsden M, Meijers CM, Jansen JE, de Kroon ML, Vrijkotte TG. Cultural variation in early feeding pattern and maternal perceptions of infant growth. Br J Nutr. 2015; 114: 481-488.

33. Mareno N. Parental perception of child weight: a concept analysis. J Adv Nurs 2013; 70: 34-45.

34. Elgar FJ, Stewart JM. Validity of self-report screening for overweight and obesity. Evidence from the Canadian Community Health Survey. Can J Public Health 2008; 99: 423-427. 